\title{
On Actualist and Fundamental Public Justification in Political Liberalism
}

\author{
Thomas M. Besch ${ }^{1,2}$
}

Public justification in political liberalism is often conceptualized in light of Rawls's view of its role in a hypothetical well-ordered society as an ideal or idealizing form of justification that applies a putatively reasonable conception of political justice to political matters. But Rawls implicates a different idea of public justification in his doctrine of general reflective equilibrium. The paper engages this second, more fundamental idea. Public justification in this second sense is actualist and fundamental (rather than ideal or idealizing and conception-applying). It is actualist in that it fully enfranchises actual reasonable citizens. It is fundamental in that political liberalism qualifies conceptions of political justice as reasonable to begin with only if they can be accepted coherently by actual reasonable citizens. Together, these features invite the long-standing concern that actualist political liberalism is objectionably exclusionary. I argue that the exclusion objection, while plausible, is more problematic in own right than it seems if actualist and fundamental public justification hypotheticalizes and discursive respect is compatible with substantive discursive inequality. This leaves proponents and critics of political liberalism with deeper questions about the nature of permissible discursive inequality in public justification.

Thomas M. Besch

thomas.besch@whu.edu.cn; thomas.besch@sydney.edu.au; https://whu-cn.academia.edu

1 School of Philosophy, Wuhan University, Wuhan 430072 Hubei, China

2 Honorary Research Associate, Department of Philosophy, The University of Sydney, Sydney, NSW 2006, Australia 


\section{Introduction}

Recent discussions of public justification in political liberalism often adopt a perspective that John Rawls foregrounds in his account of a well-ordered society at the second stage of his theory, Justice as Fairness (or JF): ${ }^{1}$ they discuss public justification with a focus on the stability of an idealized social order, while conceptualizing public justification in ideal terms and as applying a putatively reasonable conception of justice to political matters (I elaborate on this below). But a different idea of public justification is in play in Rawls's doctrine of general reflective equilibrium. This discussion explores this second, arguably more fundamental idea of public justification. I focus exclusively on first-generation, Rawls-type political liberalism (as advanced by Rawls and political liberals like Stephen Macedo or Charles Larmore), ${ }^{2}$ interpret its idea of public justification in light of the doctrine of general reflective equilibrium, and address limits of the idea so understood. On the reading suggested here, public justification, in one role, is actualist and fundamental (rather than ideal and conception-applying). It is actualist insofar as it fully enfranchises actual reasonable citizens. It is fundamental in that political liberalism counts conceptions of political justice, including JF, as reasonable in the first place only if they can equally be accepted coherently by actual reasonable citizens. Together, these features invite a familiar concern: since political liberalism from the ground up prioritizes the standpoint of citizens that it regards as reasonable, it seems objectionably exclusionary. I argue that this long-standing objection-call it the exclusion objection-is more problematic in its own right than it seems if actualist and fundamental public justification hypotheticalizes and the kind of equal respect that public justification allocates to people allows for substantive discursive inequality-in a sense to be detailed later. This leaves proponents and critics of Rawls-type political liberalism with deeper questions about the nature of permissible discursive inequality in actualist public justification. ${ }^{3}$

My discussion proceeds as follows. To elaborate further on my topic and aims, sections 2 and 3 provide needed background. I distinguish two ideas of public justification and two ideas of equal respect in Rawls-type political liberalism (as I address only this kind of view, I often drop the qualifier "Rawls-type"). This discussion focuses on actualist (rather than ideal) public justification that reflects a conceptionconstraining (rather than conception-dependent) form of respect, namely, discursive respect (Besch 2014). Sections 4 and 5 read Rawls's doctrine of general reflective equilibrium as suggesting a requirement of actualist and fundamental public justifiability. Section 6 relates this to JF's Original Position (OP) and the aim of reasonable overlapping consensus. Section 7 contrasts the proposed reading with Jonathan Quong's reading of public justification in Rawls: both readings see public justification

\footnotetext{
${ }^{1}$ See Rawls and Kelly, 2001 and 2005; Weithman 2011, 2015 and 2017; Gaus 2011; see also the discussion of various stability-centric claims about the role of public reason in Lister 2017.

${ }^{2}$ Rawls and Kelly, 2001, 2005; Macedo 1991; Larmore 2015 and 2008, part II, and 1996, chapters 6 and 7. ${ }^{3}$ Actualist readings of public justification in Rawls-type political liberalism are around for a long time, but they rarely take it to be fundamental or focus on the political role of reflective equilibrium: see Hampton 1989 and 1993; Campos 1994; Forst 1994; Wenar 1995; Estlund 1998; Besch 1998; Gaus 1999; Mulhall and Swift 1999; see also the notes to sections 4 and 5, below. The view suggested here develops further the "deep view" of public justification: see [omitted for blind review] and [omitted for blind review].
} 
as fundamental in political liberalism, but they disagree about the nature of political liberalism's commitment to extend equal respect to reasonable people.

Section 8 turns to the exclusion objection. In political liberalism, political legitimacy

is a function of what is publicly justifiable to "reasonable" people, yet its idea of reasonableness seems parochial. Contrary to one line of criticism, this coheres with salient "public reason intuitions" (Enoch 2015, p. 114ff); but it still is objectionably exclusionary. Sections 9 and 10 then consider whether hypotheticalization can accommodate the exclusion objection. To this end, I ask whether Larmore-type hypotheticalized actualist public justification (or LAJ) can model equal discursive respect. Two things emerge. First, LAJ can allocate discursive standing that is equal formally, but not substantively, or in terms of its discursive purchase (for now, think of discursive purchase as the measure of influence that an agent's discursive standing accords her in justification). Yet, second, LAJ nevertheless can model equal discursive respect if it allocates discursive standing that does not impermissibly differ in discursive purchase. LAJ's ability to model equal discursive respect hence turns on its ability to avoid impermissible substantive discursive inequality. As section 11 concludes, this marks a matter of concern not only for political liberalism, but for the wider family of conceptions of acceptability-based justification.

\section{Public Justification and Equal Respect}

To say that a salient political thing, $\varphi$ (e.g., exercises of political power, a political principle, or a conception of political justice), is publicly justifiable is to say, roughly, that $\varphi$ is authoritatively acceptable by relevant people; alternatively, it is to say that $\varphi$ is justifiable on the basis of public reasons, i.e., reasons that are so acceptable. In political liberalism, I assume, this standard refers to $\varphi$ 's equal acceptability by reasonable citizens, while the view that political things must be so acceptable reflects a view of what it takes to extend a form of equal respect to reasonable citizens in relation to such things. Yet political liberalism employs this standard in two roles-or, say, it adopts two ideas of public justification-and it puts to work two different ideas of equal respect. I address both things in turn.

One role of the standard just mentioned is internal to Rawls's model of a wellordered society. Within this model, public justification, or public reason giving that "aims for" public justification (Rawls 2005, p. 465), is carried out by the reasonable citizens of a society that is well-ordered by JF; these citizens accept JF as reasonable and they employ it as a shared basis of justification in matters of basic justice. If we understand things in such terms, to say that $\varphi$ is publicly justifiable is to say something like:

IJ For a society that is well-ordered by a conception of political justice, $\psi$, and

Call public justification in this sense ideal justification: it is ideal in that it 
of that society-citizens, moreover, who already accept a (putatively) reasonable conception of political justice and use it as a shared basis of justification. Where public justification is construed in such terms, it tends to be construed as conception-applying, i.e., as applying a (putatively) reasonable conception of political justice to salient political matters.

Needless to add, it can be a relevant result that a given political thing is IJ-justifiable, or that, for a given $\psi$, practices of IJ-justification could contribute to the stability of a well-ordered society, e.g., in relation to relevant assurance problems. ${ }^{4}$ But it is equally plain that there is more to the theme of public justification in political liberalism. Political liberals often refer to public justification as requiring equal acceptability by actual reasonable people in the actual world. So construed, the claim that $\varphi$ is publicly justifiable becomes a claim like:

AJ For the actual citizens of an actual Western democratic society: $\varphi$ is equally acceptable by all reasonable citizens (or, perhaps, all citizens insofar as they are reasonable), or is justifiable by reasons that are.

Public justification in this sense is actualist justification: the standard of public justification here applies to actual discursive practice, and public justification includes in its constituency on fully enfranchised footing actual reasonable people. (I address the role of AJ-justification in political liberalism in sections 3 and 4, and turn to Larmore's hypotheticalizing variant of AJ-justification in sections 9 and 10.)

Two comments are called for. First, public justification in political liberalism enfranchises reasonable people, but there is little consensus in the field about the content of this idea of the reasonable. But we need not go into much detail: only two things matter now. First, reasonable citizens do not reject political liberalism's most important liberal political values (whatever exactly these are), although they might not also accept JF, as a token member of the family of political liberalism. ${ }^{5}$ Second, as proponents and critics of political liberalism alike observed, reasonableness is a complex virtue such that intelligent and conscientious citizens in good moral standing might not qualify as reasonable. This invites concerns about the inclusiveness of public justification, or lack thereof-I return to this below.

Second, the distinction between IJ-justification and AJ-justification marks ideal types that are suggested by two roles of public justification in political liberalism. Beyond ideal types, it is not always straightforward whether a given conception of public justification instantiates, or leans toward, ideal or actualist justification. This is so not least because all acceptability-based justification hypotheticalizes, however minimally, and hence idealizes in one sense of the word (Enoch 2015; Besch 2019). For it must qualify the discursive input that it counts as authoritative, or as contributing to justification. E.g., to be authoritative, discursive input must be respectable, thoughtful, coherent, and so on. Correspondingly, there can be highidealization actualist justification. E.g., we might take $\varphi$ to be publicly justifiable to

\footnotetext{
${ }^{4}$ E.g., it is one concern of Quong's internal conception to show that JF itself would equally acceptable by the hypothetical reasonable citizens of JF's well-ordered society: see Quong 2011 and 2012. Gaus and Weithman foreground assurance problems: Gaus 2011, p. 315ff; Weithman 2011, chapter II.

${ }^{5}$ For one account of reasonableness in Rawls-type public justification: see [omitted for blind review] and [omitted for blind review]. See also Enoch 2015.
} 
actual people here and now only if they could still accept $\varphi$ if they were fully reasonable citizens of a well-ordered society. For now, though, I may simplify. Thus, I shall assume that public justification is construed as ideal if it is construed as situated in a hypothetical well-ordered society and as fully enfranchising only the hypothetical reasonable citizens of that society who accept a (putatively) reasonable conception of political justice. It is construed as actualist if it is construed as situated in an actual society and as fully enfranchising actual reasonable citizens who (qua reasonable) accept political liberalism's most important political values.

A commitment to actualist justification is evident in the works of Macedo and Larmore. For Macedo, public justification aims to justify things on the basis of good reasons and it aims to respect reasonable citizens as free and equal-and Macedo takes the latter to call for justifications on grounds that are equally acceptable by actual reasonable people "such as they are" (Macedo 1990, p. 281; Hadfield and Macedo 2012, p. 10). However, political liberalism construes the first aim from the perspective of the second: it defines the goodness of good, publicly justifying reasons as "entirely a function of their capacity to gain widespread agreement among reasonable people" (Macedo 1990, p. 282). This applies to actual reasonable people and all public reasons, including public reasons that establish principles of political justice as reasonable or exercises of political power as legitimate.

Similarly, Larmore sees equal respect as the "moral basis of the liberal principle that the fundamental rules of political association are legitimate only if they can be the object of reasonable agreement" (Larmore 2015, p. 79). But for political liberalism, reasonable people are properly respected as equals only if the political principles that apply to them are as justifiable "to them from their perspective as they presumably are to us" (ibid, p. 78). This refers to reasonable people, including actual people, "to which such principles are to apply" (Larmore 1996, p. 137), and it specifies a condition that all political principles must meet.

Next, these two authors evidently do not take public justification to serve in a merely conception-applying role: rather than requiring equal acceptability only of (hypothetical) practices of reason giving that apply a given, putatively reasonable conception of political justice to salient political matters, they take it that such conceptions must be suitably acceptable by reasonable citizens, or be justifiable by reasons that are, to be reasonable in the first place.

Rawls, too, understands public justification along such lines. For Rawls, no conception of political justice is reasonable unless it is equally acceptable coherently by actual reasonable citizens, or so I claim. This in effect employs a requirement of public justifiability as a requirement of theory-selection in the domain of the political, and so applies it at a level of thought, argument, or decision-making that is fundamental in political liberalism's order of justification. To read political liberalism in such terms is to read it as a political constructivism that puts center stage an idea of actualist public justification.

I now turn to equal respect, or two ideas of equal respect and two views of its relationship to public justification. One view comes with (but is not tied to) Rawls's model of a well-ordered society. The reasonable citizens of JF's well-ordered society respect each other as equals, but they look to JF, or its values of justice and public reason, to define what this calls for; and as JF prescribes that they comply with a duty of civility to engage in public reason giving in political matters, equal respect commits 
them to do so (Rawls and Kelly 2001, p. 116f). This employs equal respect as a conception-dependent constraint-a constraint the content of which is defined by, or depends on, a (putatively) reasonable conception of political justice. To respect others accordingly is to respect them as recipients of justice, as defined accordingly; so construed, equal respect calls for public reason giving if a reasonable conception of political justice prescribes it. ${ }^{6}$

On another, more republican or constructivist view, equal respect, rather than depending on a reasonable conception of justice, constrains what conceptions of justice count as reasonable to begin with. This employs equal respect in a conceptionconstraining role. On this view, or one version of it, political things accord with equal respect for relevant people only if they are equally justifiable to, or acceptable by, these people. This is the kind of equal respect in which Macedo and Larmore anchor public justification. Equal respect in this sense requires respecting others not merely as recipients, but as equal authorities or co-authors of political justice and justification (Forst 2017a, p. 134). Thus, it involves according others a justificatory say, or discursive influence, in practices of reason giving in relation to what counts as just, justified, or reasonable to begin with. In different terms, equal respect in the conceptionconstraining sense involves according others constitutive discursive standing and hence takes the form of discursive respect (Besch 2014 and 2019).

On the reading suggested here, political liberalism adopts an idea of actualist public justification that expresses, or models, a commitment to extend equal discursive respect to actual reasonable citizens. Macedo and Larmore are more forthcoming about this commitment than Rawls, but he, too, adopts it. True, his model of a well-ordered society construes equal respect as conception-dependent and public justification as ideal and, many assume, conception-applying. But this model is part of JF, and JF depends for its reasonableness on its equal acceptability by actual reasonable citizens. And, I submit, it is this deeper requirement-one that applies to JF as a whole-that expresses, or models, the commitment to equal discursive respect.

\section{Three Levels of Argument}

It is useful here to distinguish three levels of argument in Rawls's mature view of domestic justice. Thus, let me consider in broad terms the discursive structure of that view.

This structure, I submit, is roughly as follows. Rawls addresses reasonable citizens of a Western liberal democracy, and submits to their consideration answers to questions such as:

Q1 What must a conception of political justice be like to be able to provide a basis for political legitimacy within a Western liberal democracy?

\footnotetext{
${ }^{6}$ On this picture, also public reason giving is conception-dependent: reasonable people are to reason publicly if political justice, as specified by a reasonable conception of justice, requires it. Some authors who see public justification as IJ-justification think of matters in such terms: e.g., see Quong 2014, p. 273. This sits well with non-constructivist views of public justification: it suggests that the public justifiability of political things is required only if a reasonable conception of justice prescribes that they must be so justifiable-where the reasonableness of the latter hence cannot depend on its public justifiability: see Enoch 2015, Wall 2016.
} 
Q2 If such a conception must take the form of a political liberalism, what view of that kind should be adopted?

To answer Q1, Rawls argues that $\varphi$ can provide a basis for political legitimacy in a society of the relevant kind only if $\varphi$ is equally acceptable by the reasonable citizens of that society, and that $\varphi$ must hence be political in scope and form of justification and liberal in content-i.e., roughly, $\varphi$ must only regulate that society's domain of the political and construe equal acceptability by its reasonable citizens as politically justifying, while only containing liberal political values. To make this case, Rawls argues that a conception of justice cannot be equally acceptable by reasonable citizens unless it can attain an overlapping consensus between their reasonable comprehensive doctrines, while only a political and liberal conception can accomplish this. Call this Rawls's level-1-arguments.

Rawls's answer to Q2 takes the form of JF-which itself has two stages, S1 and S2. S1 includes JF's argument from the Original Position (or OP) to JF's principles of justice (Rawls and Kelly, 2001, p. 14-18, 42-52). OP proposes a model of rational choice under reasonable constraints. Rawls claims that reasonable people, if they were to choose principles of basic justice, would do so as modelled by OP. And he argues that they would adopt JF's principles. Call this Rawls's level-2-arguments.

$\mathrm{S} 2$ engages the theme of stability, amongst other things. Rawls defines an ideal of the good citizen-i.e., a reasonable and rational citizen who endorses JF-and argues that a society of such citizens that is well-ordered by JF would be stable (Rawls 2005, p. 11f, 16f, 22-28, 66-82, 94, 97f; Rawls and Kelly, 2001, p. 8f, p. 26-29, 116f). This is because, in this society, JF would serve these citizens as a shared basis of public justification that they can draw on to secure stable agreement in matters of basic justice, while JF would order this society so as to encourage "cooperative virtues of political life" (Rawls and Kelly, 2001, p.116f)-e.g., reasonableness, fairness, or the disposition to comply with a duty of civility to exercise public reason in salient matters-that "underwrite" a willingness to cooperate with others "on a footing of equality and mutual respect." (Ibid.) Rawls here employs an idea of public justification as ideal and, many assume, conception-applying. Call the arguments at JF's second stage Rawls's level-3-arguments. ${ }^{7}$

What matters here are Rawls's level-1-arguments. They are more fundamental in political liberalism's order of justification than his level-2-arguments or his level-3arguments. This is so since Rawls's answer to Q2 supposes that Q1 can be answered in a way that supports the project of a political liberalism: the answer to Q1 sets a frame that a JF aims to fill out. And, we shall now see, Rawls's level-1-arguments put centre stage an idea of actualist public justification.

\footnotetext{
${ }^{7}$ Some authors suggest that JF's stability-centric considerations are part of the argument from OP: Gaus and Schoelandt 2017, p. 149; Weithman 2017. On this view, it is from the perspective of the parties of $O P$ that stability-centric considerations bear on the selection of principles of justice. I foreground a different perspective. For Rawls, JF is reasonable only if JF as a whole is acceptable from the perspective of actual reasonable citizens (see below). It is from this perspective that the role of the argument from $\mathrm{OP}$ and JF's stability-centric considerations vis-à-vis each other and the task of principle selection must be acceptable. But it is possible that, from this perspective, reasons can arise to revise OP or its role on the basis of stability-centric considerations. Hence, it is best to see Rawls's level-3-arguments and his level-2-arguments as distinct stages of his overall view.
} 


\section{Toward Actualist and Fundamental Public Justification}

With this I turn to the political role of Rawls's criterion of reflective equilibrium (CRE). ${ }^{8}$ To assist my reading, I make an assumption that is implicit in the above already. In the present context, views to the effect that political things depend for a salient political merit (e.g., reasonableness, or legitimacy), on being equally acceptable by reasonable people reflect a commitment to the public justifiability of these things, or of claims to the effect that they have that merit. With this in mind, consider CRE.

For Rawls, any conception of political justice, "to be acceptable, must accord with our considered convictions, at all levels of generality, on due reflection, or in what I have called elsewhere "reflective equilibrium"." (Rawls 2005, p. 8) $\varphi$ is in reflective equilibrium with a set of views, $S$, only if $\varphi$ coheres with $S$, each member of $S$ is well-considered, and $S$ is internally coherent (ibid). ${ }^{9}$ Thus, any conception of political justice, including JF, must cohere with the considered judgments of relevant people.

Much depends on the standpoint from which reflective equilibrium is to be sought. Rawls highlights three standpoints, including "that of the parties in the original position, that of citizens in a well-ordered society, and finally, that of ourselves-of you and me who are elaborating justice as fairness and examining it as a political conception of justice" (ibid, p. 28). For CRE's purposes, the third standpoint is essential. As Rawls highlights, the other two standpoints are not actually adopted by anyone, but belong to JF's conceptual inventory-where JF is but one theory of justice that must be assessed from the standpoint of "you and me." Thus, the test of reflective equilibrium tests how well a conception of justice

as a whole articulates our more firm considered convictions of political justice, at

Accordingly, JF aims to articulate "our more firm considered convictions," while " $[w] e$ decide whether the whole conception is acceptable by seeing whether we can endorse it upon due reflection" (Ibid, p. 94; all emphases added).

Who is referred to here as "you and me"? ${ }^{10}$ Evidently, actual people. ${ }^{11}$ But not

\footnotetext{
${ }^{8}$ The below adds to my discussion in [omitted for blind review]. That CRE has a political role has been observed before: see Lister 2008; Nielsen 1994; Besch 1998.

${ }^{9}$ On reflective equilibrium: see Rawls 2005, p. 28, 45; Rawls and Kelly, 2001, p. 30ff; Rawls 1971, p. 20f, 48-51; see also Daniels 1979 and 1980; Raz 1882; Scanlon 2002; Knight 2006; Kelly and McGrath 2010; Laden 2014; Baderin 2017.

${ }^{10}$ For Onora O'Neill, this marks important differences between Rawls's view of public reason and her Kantian view: O'Neill 2015 and 1996, chapter 2.

${ }^{11}$ This is worth noting: Rawls also discusses CRE in relation to the hypothetical citizens of JF's well-ordered society: Rawls and Kelly, 2001, p. 9 f.
} 
political liberalism in part because he believes that $\mathrm{JF}$, if it takes this form, can meet CRE. But CRE from the outset disqualifies JF if the group of people for whom JF must meet CRE included on equal footing people who cannot coherently accept political liberalism's most important liberal political values. Thus: the reflective equilibria of actual citizens count, but only those citizens count who can coherently accept these values, namely, citizens who are reasonable in political liberalism's sense.

But if the reflective equilibria of actual reasonable citizens count, they count equally. This much springs from political liberalism's commitment to extend equal discursive respect to reasonable citizens. Thus: conceptions of political justice must attain interpersonal reflective equilibrium-or general reflective equilibrium, as Rawls calls this (Rawls 2005, p. 388, and 2001, p. 31). Thus, CRE specifies in what way $\varphi$ must be acceptable for each reasonable person for this to count toward $\varphi$ 's equal acceptability by-or, with the above assumption, $\varphi$ 's public justifiability to-all reasonable people. Textual evidence confirms this: Rawls writes that JF, when it attains public justification, is affirmed in reflective equilibrium (Rawls and Kelly, 2001, p. 29, and 2005, p. 388).

This suggests we attribute to Rawls Actualist Public Justification (for conceptions of political justice, $\varphi$ ):

APJ $\varphi$ is reasonable if and only if $\varphi$ is equally acceptable coherently by, or

where $\varphi$ is "equally acceptable coherently" by $\alpha$ and $\beta$ only if each can accept $\varphi$ coherently in CRE's sense, and citizens are "reasonable" only if they do not reject political liberalism's most important liberal political values. Some comments are called for.

\section{Some Comments}

First, Rawls distinguishes narrow and wide reflective equilibrium-which differ primarily in relation to the scope and depth of the reflection through which equilibrium is reached. Rawls prefers wide over narrow equilibrium (Rawls 1974, p. 8f; Rawls and Kelly, 2001, p. 29-32, and 2005, p. 387f). As wide equilibrium can be less conservative than narrow equilibrium, it is worth noting that Rawls's preference for wide equilibrium can cohere with his view that only a political liberalism, if anything, is equally acceptable by reasonable citizens. As we have seen, citizens here count as reasonable only if they can coherently accept political liberalism's most important liberal political values. And one way to square this with the dynamics of wide reflective equilibrium is to distinguish, on the lines of what we saw earlier, between the perspective from which an agent pursues reflective equilibrium and, say, her actual deliberative field, or the set of views, widely conceived, that she actually accesses, considers or tries to balance in the process. I take it that reflective equilibrium can be wide even if it is perspectival or not standpoint-neutral-i.e., even if some views or commitments remained fixed points throughout an agent's effort to attain wide equilibrium in her deliberative field. Thus, political liberalism's most important liberal political 
values, or a commitment not to reject them, here mark the perspective from which reasonable citizens pursue wide reflective equilibrium, rather than being mere items in their deliberative field. ${ }^{12}$

Second, APJ-justification is robustly public (Postema 1995). Rawls does not claim merely that a reasonable conception of political justice will also be acceptable by reasonable people. He makes the stronger, constructivist claim that the reasonableness of such a conception depends on, or is (partly) constituted by, its acceptability by reasonable citizens. In the terms used earlier, APJ accords reasonable people a justificatory say on what conception of political justice qualifies as reasonable, or extends them discursive respect in such matters. Thus, if actual reasonable citizens cannot actually accept $\varphi$ coherently, APJ counts this as (defeasible) evidence in own right that $\varphi$ is not reasonable; and if they cannot actually reject $\varphi$ coherently, APJ counts this as (defeasible) evidence in its own right that $\varphi$ is reasonable.

Third, APJ is fundamental in political liberalism's order of justification. Conceptions of political justice provide a basis for conditionally reasoned justifications, but these justifications can have only a provisional, pro tanto authority (Rawls 2005, p. 386). After all, they depend for their authority on the reasonableness of the conceptions they draw on. Accordingly, APJ relates to such conceptions and conception-dependent justifications like standards of theory-acceptance relate to the theories they apply to: the latter depend for their authority on meeting the former.

Fourth, I may leave open here whether APJ can be applied to political principles, value judgements, or other political things, directly in a manner that would leave no meaningful justificatory role for conceptions of political justice. If it can be so applied, Rawls's political liberalism is structurally closer to the views of first-generation political liberals like Macedo and Larmore than it would otherwise seem. I also leave open whether reasonableness in APJ's sense is a family trait of conceptions of justice. If it iswhich is an option Rawls seems to favor-then APJ by itself underdetermines the public choice of a token conception of political justice.

Fifth, APJ helps to explain why "political liberalism applies the principle of toleration to philosophy itself" (ibid, p. 10). For Rawls, to apply this principle to philosophy is or involves requiring conceptions of political justice to avoid reasonable disagreements between reasonable citizens-or to be neutral in a justificatory sense. However, Rawls takes it that if $\varphi$ is reasonably rejected by some reasonable citizens and reasonably accepted by others, then $\varphi$ is the subject of reasonable disagreement. ${ }^{13}$ But if $\varphi$ is the subject of such disagreement, then there is evidence that $\varphi$ is not equally acceptable by reasonable citizens. Thus: if conceptions of political justice must meet APJ, then there is reason for them to avoid reasonable disagreement.

Sixth, a disclaimer: it is beyond what I can do here to show how APJ sits with many of Rawls's key claims, including especially his claim that only a political liberalism can provide a basis for political legitimacy (but I address this in [omitted for blind review] and [omitted for blind review]). For now, I only relate APJ to JF's Original Position,

\footnotetext{
${ }^{12}$ Thus, Rawls's wide equilibrium can be more conservative than a method of "balance and refinement" (DePaul 1993, p. 25-43). Nor is it a "free" equilibrium (Gaus 2011, p. 311ff). Rawls might not expressly restrict the deliberative field within which equilibrium is sought, but considers its pursuit only from reasonable perspectives.

${ }^{13}$ This draws on the account of reasonable disagreement in Rawls suggested in [omitted for blind review]. See also Larmore 2015, p. 68-74.
} 
reasonable overlapping consensus (see below), and Rawls's idea of political legitimacy

(section 8). Yet, plainly, APJ leans toward political liberalism: the search for a able people-i.e., people who do not reject political liberalism's most important liberal political values.

\section{The Original Position and Overlapping Consensus}

JF's Original Position (OP) and the aim of reasonable overlapping consensus are often taken to play important justificatory roles in Rawls's view. It is hence instructive to relate them to APJ. I start with OP.

OP is often regarded as expressing an idea of practical reason such that if any actual citizen cannot coherently accept OP's results, such as JF's principles, then this must be owed to that person's unreasonableness or irrationality. ${ }^{14}$ But this cannot be right. If conceptions of political justice depend for their reasonableness on their equal acceptability by reasonable citizens, the reasonableness of these citizens cannot depend on their acceptance of OP's results. In this light, consider:

[OP] models what we regard-you and I, here and now-as fair and reasonable conditions for the parties, who are rational representatives of free and equal, reasonable and rational citizens (...). [OP] also models what we regard as appropriate restrictions on reasons for adopting a political conception of justice for [the basic structure of society] ... [W] e conjecture that the conception of political justice the parties would select is the conception that you and I, here and now, would regard as reasonable and rational and

OP models what "you and I" see as reasonable and rational deliberation, or as proper constraints on reasons to adopt a conception of political justice. Rawls stresses that OP's success as such a model turns on whether OP's results match what "you and I" on reflection regard as reasonable and rational, or as supported by the best reasons. Accordingly, he writes that OP is "a means of public reflection and self-clarification" that aims to help "us" attain "deeper self-understanding" and "greater coherence among all our judgements," with the help of which "we can attain wider agreement among one another" (Rawls 2005, p. 26). And one assumption here is that "we" can tell from the standpoint of "our" considered judgments whether OP advances that end.

What people does Rawls refer to? These, I submit, are the people from the perspective of whom JF must be acceptable for it to be reasonable, namely, actual reasonable citizens. One way to interpret OP's role hence is this. OP is a reconstructive tool to draw out or clarify implications of the self-understanding of actual reasonable citizens. OP's success as such a tool depends on whether OP's results cohere with the considered judgments of these citizens-which is something they assess from the 
standpoint of their considered judgments. If they conclude that OP fits their selfunderstanding, OP succeeds in its role-in which case OP advances JF's public justification. But if OP does not succeed in its role, it does not advance JF's public justification-in which case these citizens must decide from their perspective whether to revise or reject JF. Either way, their considered judgments have the last word. ${ }^{15}$

On this reading, then, it is not the case that if actual citizens cannot coherently accept OP's results, this must speak to their unreasonableness or irrationality. In relation to actual reasonable citizens, the dependency is reversed: if they cannot on reflection coherently accept OP's results, this calls into question the reasonableness of OP's results (or JF) if this conclusion is favored by their considered judgments.

Next, consider reasonable overlapping consensus. Rawls writes:

435

436

437

438

439

440

441

442

443

444

445

Public justification happens when all the reasonable members of political society carry out a justification of the shared political conception by embedding it in their several reasonable comprehensive views. In this case, reasonable citizens take one another into account as having reasonable comprehensive doctrines that endorse that political conception ... Only when there is a reasonable overlapping consensus can political society's political conception of justice be publiclythough never finally-justified. Granting that we should give weight to the considered convictions of other reasonable citizens, this is because general and wide reflective equilibrium with respect to a public justification gives the best justification of the political conception that we can have at any given time. There is ... no public justification for political society without a reasonable overlapping consensus... (Rawls 2005, p. 387f.)

This, I submit, states a view of public justification under conditions of "reasonable pluralism" (see below) that applies to ideal and actualist public justification. Rawls draws on the link between public justification and reflective equilibrium and suggests that, under these conditions, a conception of justice, $\varphi$, can be publicly justifiable to actual reasonable citizens only if $\varphi$ can attain an overlapping consensus between the reasonable comprehensive doctrines that these citizens endorse. Specifically, the idea seems to be:

(i). $\varphi$ is APJ-justifiable only if $\varphi$ is acceptable by each actual reasonable citizen in reflective equilibrium.

(ii). In conditions of reasonable pluralism, reasonable citizens accept reasonable but incompatible comprehensive doctrines.

(iii). Hence: $\varphi$ is suitably acceptable only if $\varphi$ coheres with, or can "in some way" (ibid, p. 386) be embedded in, the reasonable comprehensive doctrines of reasonable citizens.

However, if $\varphi$ can be embedded in these doctrines, $\varphi$ attains a reasonable overlapping consensus. Thus: actualist and fundamental public justification does not

\footnotetext{
15 This is on the trajectory of Scanlon's reading of the relationship between CRE and OP: see Scanlon 2002, p. 153-157.
} 
compete with the aim of reasonable overlapping consensus, but requires that this aim can be attained. ${ }^{16}$

Observe that this coheres with the notion of reasonable pluralism, or one of the two

475

476

477

478

479

480

481

Another notion surfaces here:

[The fact of reasonable pluralism] is the fact that free institutions tend to generate 483

484

485 views that develop are a diversity of reasonable comprehensive doctrines. These are the doctrines that reasonable citizens affirm and that political liberalism must address. (Ibid, p. 36; all emphases are added.)

486

487

This entails that reasonable pluralism can obtain even if many unreasonable doctrines are present. Call this non-ideal reasonable pluralism: it can obtain in actual societies. When it obtains, political liberalism addresses only a subset of doctrines, namely, the subset that only includes reasonable doctrines of reasonable citizens. In short, given APJ, political liberalism aims at a reasonable overlapping consensus also in the real world-although in the real world, such a consensus might not be very inclusive in scope.

\section{Quong's Reading}

To conclude the reconstructive part of this discussion, I contrast the above reading with Quong's reading of public justification in Rawls's political liberalism. Since both readings take it that political liberalism requires conceptions of political justice to be publicly justifiable to reasonable citizens, it is instructive to see where they differ.

On Quong's reading, Rawls's political liberalism aims to show "how liberal rights and institutions can be publicly justified to the constituency of an ideal democratic society" (Quong 2011, p. 6; my emphasis). Accordingly,

the overlapping consensus represents the first stage in the justificatory process.

We begin by identifying the common ground that reasonable citizens would share fairness, and reasonable pluralism are assumed to ground a commitment to public reason and a liberal conception of justice, but the core ideas are not themselves subject to any test of public justification, nor do we check to see if these values can be the subject of an overlapping consensus amongst real citizens here and now. (Quong 2012, p. 51f; all emphases are mine.)

This suggests: political liberalism requires conceptions of political justice to be publicly justifiable not to "real citizens here and now," but only to "the constituency

\footnotetext{
$\overline{{ }^{16}}$ A related matter is the potential redundancy of the aim of reasonable overlapping consensus: see [omitted for blind review].
} 
of an ideal democratic society," namely, the (non-existent) reasonable citizens of a (non-existent) well-ordered society. Accordingly, it seeks an overlapping consensus only between the reasonable doctrines of these (non-existent) reasonable citizenswhere citizens and their doctrines are reasonable only if they do not reject political liberalism's most important liberal political values. Thus, public justification here is a form of ideal justification.

Quong aims to improve on what he calls the "common view" of the role of overlapping consensus in Rawls (Quong 2011, p. 163ff). According to the common view, two things hold. First, only JF's principles of justice, rather than JF as a whole, must attain a reasonable overlapping consensus. And second, OP addresses "an independently defined constituency of persons" (ibid, p. 166), rather than only reasonable citizens, i.e., citizens who are reasonable in political liberalism's sense. Quong disagrees with the common view on both counts.

Quong is right to disagree with this view on these counts. Since his political turn, Rawls elevates the role of public justification and hence of overlapping consensus: JF as a whole must be publicly justifiable to reasonable citizens-where the reasonable do not reject political liberalism's most important liberal political values (the above quotation samples Quong's view of what these are). This changes the architecture of Rawls's overall view: public justification is now part of a first, fundamental stage of argument in political liberalism.

But how should we interpret this change? This is where the reading suggested here and Quong's reading part ways. Quong seems to infer from the fact that political liberalism construes public justification as part of a first, fundamental stage of justification, and the fact that it aims to publicly justify salient things only to citizens who are reasonable in political liberalism's sense, that public justification is always ideal justification (Quong 2011, p. 6f, 138f, 166ff, 180ff). But consider where this leaves political liberalism. According to Quong, public justification would not enfranchise actual citizens-i.e., it would not check whether salient values are acceptable by "real citizens here and now" (see above)-although this

should not be misunderstood to mean that political liberalism is not also addressed to real citizens ... Each of us ought to recognize [political liberalism's political values] as very great values, ones which should regulate the way in which we treat our fellow citizens. The normative conclusions of political

However, public liberalism would address actual citizens only in the weak sense of treating them as recipients of public justification. Political liberalism would expect their compliance with its conclusions. But it would not make these conclusions depend for their reasonableness or justification on their equal acceptability by any actual citizen here and now. No actual citizen here and now would have a justificatory say in relation to the content of political justice or its justification. ${ }^{17}$

\footnotetext{
${ }^{17}$ That Quong-type public justification can address actual citizens in one sense is sometimes overlooked: e.g., see Schoelandt 2015, p. 1039.
} 
But this cannot capture the nature of political liberalism's commitment to equal respect, or so I claim. Political liberalism respects actual reasonable citizens not merely as recipients, but as authorities or co-authors of public justification: it accords them a justificatory say, or discursive respect. Yes, it expects actual citizens to abide by the normative conclusions of political liberalism. But it does this insofar as these conclusions can be supported by a reasonable conception of political justice, where the reasonableness of such conceptions depends on their acceptability by actual reasonable citizens. Thus: public justification is part of a fundamental stage of justification and aims to publicly justify salient political things only to citizens that it regards as reasonable. But this reflects a commitment to actualist justification: Rawls's political liberalism is fundamentally a form of actualist, rather than ideal, political liberalism.

\section{Political Legitimacy and the Exclusion Objection}

With this I turn to the exclusion objection. Political liberalism construes the legitimacy of exercises of political power as a function of their justifiability to citizens who do not reject political liberalism's most important liberal political values. It has often been argued that this renders the view objectionably exclusionary. ${ }^{18}$ What I will do in the remainder of this discussion is to consider whether Larmore's hypotheticalizing variant of actualist public justification can accommodate this objection. This will bring to the fore deeper questions about the nature of discursive (in)equality in actualist public justification.

How does APJ relate to Rawls's liberal principle of legitimacy (LPL)? According to LPL, political power must be exercised "in accordance with a constitution the essentials of which all citizens may reasonably be expected to endorse in the light of principles and ideals acceptable to them as reasonable and rational" (Rawls 2005, p. 217). This refers to principles and ideals that are justifiable as reasonable and rational by a reasonable conception of political justice. But to be reasonable, such conceptions must be equally acceptable by actual reasonable citizens-where, as suggested above p.5, this expresses, or models, an idea of equal discursive respect. Thus, Rawls adopts a respectbased actualist form of justificatory liberalism: to properly respect actual reasonable citizens, exercises of political power must be justifiable on grounds that are equally acceptable by them. ${ }^{19}$

Central here is the idea that citizens are owed a measure of discursive influence at a fundamental level of political justification-or a share of "discursive power" (Forst, 2017b, p. 10f), or discursive standing of relevant discursive purchase (see below). This places weight on the participation value of public justification ([omitted for blind review]). That is, the point is not simply that political power must be based on grounds that relevant people can accept (say, at some level of idealization); the point is, rather, that their actual ability or inability to accept a conception of justice is to have traction on its eligibility for the role. This is part of the non-domination or emancipatory upshot

\footnotetext{
${ }^{18}$ This objection has been made since the early days of Rawls's political turn: e.g., see Hampton 1989 and 1993; Campos 1994; Besch (1998); Friedman (2000).

${ }^{19}$ I discuss political legitimacy in Rawls in more detail in [omitted for blind review].
} 
of Rawls's view of political legitimacy. ${ }^{20}$ Of course, a flip-side here is that only reasonable citizens get to have such influence. Unreasonable citizens are not, or not in the same way, respected as co-authors of public justification.

Does this cohere with political liberalism's "public reason intuitions," as Enoch calls them (Enoch 2015, p. 114ff)? The phrase refers to the two-fold view that political power can be reconciled with the freedom and equality of citizens only if it is justifiable to them, and equally so. For Rawls, this reconciliation requires such power to be justifiable on grounds that are equally acceptable by reasonable citizens. Note that it not clear whose freedom and equality political liberalism aims to reconcile with political power. Some critics, notably Enoch, assume that Rawls's political liberalism initially aims to reconcile the freedom and equality of all citizens with political power, or at least not only reasonable people (ibid, p. 122-126). This makes political liberalism an easy target for an internal version of the exclusion objection. For if political liberalism pursues inclusive aims, it does not achieve them: the equal justifiability of political power to citizens who are reasonable in political liberalism's sense might reconcile their freedom and equality with political power, but it does little to reconcile the freedom and equality of other citizens with political power (ibid).

But there is another, perhaps more charitable reading that clarifies the terms of the problem that political liberalism aims to solve in light of the solution it offers. Macedo tells us how: political liberalism, he notes, respects as "free and equal (...) all those who pass certain threshold tests of reasonableness: we respect those whose disagreement with us does not impugn their reasonableness" (Macedo 1991, p. 47, 71). Thus, what political liberalism aims to reconcile with political power is the freedom and equality not of all citizens, but of all citizens that it respects as free and equal, namely, reasonable citizens. As far as the public reason intuitions are concerned, therefore, the exclusion objection misfires as a stretch of internal criticism: in political liberalism, the equal justifiability of exercises of political power to reasonable citizens is all that is called for to begin with.

Still, the exclusion objection has much appeal. If the legitimacy of political power is a function of its justifiability, and if justification must model equal discursive respect, then such power must be equally justifiable to everyone to whom such respect is owed. But why should it be owed only to citizens who do not reject political liberalism's most important political values? Why is it a non-rejection of these things on which an entitlement to exercise (a full measure of) discursive influence at a fundamental level of political justification hinges? Again, I set aside what values are built into APJ's idea of the reasonable. Yet, arguably, many citizens might not qualify as reasonable in political liberalism's sense. Thus, the exclusion objection articulates the concern that it is in one form or another impermissible-or unjust, arbitrary, dogmatic, and so on-to extend equal discursive respect only to citizens who are reasonable in that sense.

It remains open how Rawls-type political liberalism can plausibly respond to the exclusion objection without at the same time undermining itself. Consider just two of the more self-suggesting responses. First, public justification might fully enfranchise

\footnotetext{
${ }^{20}$ But we should not overstate the import of the influence that APJ accords the reasonable: there may not be emancipatory trickle-down effects such that an agent's discursive influence at the level of assessments of the reasonableness of conceptions of justice translates into influence in lower-order assessments of the legitimacy of exercises of political power-and it will often only be the latter kind of influence that demonstrates in the eyes of agents that their perspectives matter politically.
} 
(some) people who are not reasonable in political liberalism's sense-people, that is who cannot accept (all of) its most important liberal political values. But it must then be doubtful that a political and liberal conception of justice can be claimed to be the values it builds into APJ's idea of the reasonable to unreasonable people. But then APJ-justification cannot be fundamental; and so one question will be how this could square with the commitment to accord reasonable citizens discursive respect at a fundamental level of political justification. Either way, political liberalism seems pushed to sacrifice something essential to the project.

\section{Hypotheticalizing Actualist Public Justification?}

Maybe actualist public justification can be more inclusive and prioritize reasonableness if it includes unreasonable citizens in its constituency, but recognizes discursive input as counting toward public justification only insofar as it is reasonable. Can hypotheticalization help?

In passing, I note two things. First, hypotheticalization here is not ad hoc, as Enoch hypotheticalized actualist public justification "idealizes" (in one sense) around its fringes, but it fully enfranchises actual reasonable citizens.

Larmore expressly hypotheticalizes actualist public justification, or what he calls "rational dialogue" (Larmore 2015, p. 74-87, and 1996, p. 134ff). He concedes that political liberalism excludes some people in some way, such as unreasonable citizens or people who do not "prize most highly the norms of rational dialogue and equal respect" (Larmore 1996, p. 142, and 2015, p. 83). Still, he insists, exercises of political power must be justifiable to citizens more generally on the (perhaps counterfactual) assumption that they are reasonable. ${ }^{21}$ Thus, in relation to the unreasonable, what counts toward public justification is what they would accept if they were reasonable. This coheres with the idea of equal respect:

[T]he moral idea of respect for persons lying at the heart of political liberalism

The point: Larmore-type hypotheticalized actualist public justification (or LAJ) does

\footnotetext{
${ }^{21}$ Larmore 2015, p. 83. He reads Rawls's view of political legitimacy in such terms: ibid., p. 75f, and 1999, p. 609 f.
} 
justificatory say not only to reasonable people, but counts exercises of this say as authoritative only insofar as they are reasonable. ${ }^{22}$

Can LAJ accommodate the exclusion objection? One way to pick up the stick is to ask whether LAJ can model equal discursive respect. Upfront, this is doubtful: LAJ, too, prioritizes the reasonable. Yet on reflection, a more nuanced assessment is needed, or so we shall find.

To start with, recall that all acceptability-based justification must qualify the discursive input it counts as authoritative, and so will hypotheticalize. E.g., to justify, acceptability must be respectable, thoughtful, coherent, or some such. This means that discursive equality must be seen in light of relevant authoritativeness constraints-or, in the present case, a reasonableness threshold. With this in mind, consider now discursive equality. ${ }^{23}$

Actualist public justification expresses, or models, an idea of equal discursive respect in that it accords people an equal justificatory say, or equal constitutive discursive standing. Now, one especially salient respect in which discursive standing can be equal or unequal is its discursive purchase. What is this? Roughly, discursive purchase is a function of the discursive influence that an agent's discursive standing accords her in justification, or on its outcomes, given her actual deliberative resources (widely conceived so as to include the entire range of views, volitions, commitments, capacities, and so on, that she draws on in her practical thought). When we consider discursive purchase, we consider the participation value of justification: we consider how standards of justification relate to the agents they apply to, or range over, and what level of discursive influence in justification these standards allocate these agents ([omitted for blind review]).

This influence comes in degrees. Consider two justification practices, JP1 and JP2, that accord average Betty a justificatory say, but apply to her different authoritativeness constraints. JP1 counts her rejection of $\varphi$ as authoritative if it is locally coherent in light of her actual deliberative resources. JP2 counts her rejection of $\varphi$ as authoritative only if she would still reject $\varphi$ if she was fully or ideally rational. It is plain that JP1 can give Betty's actual perspective traction in justification in a way in which JP2 does not. As JP1 sets its bar for authoritativeness at a readily accessible level, her justificatory say can be meaningful: if she cannot actually accept $\varphi$ coherently, this in its own right can count as (defeasible) evidence that $\varphi$ is not justified. Hence, her discursive standing is high in purchase. Not so in JP2, for better or worse. If her actual say is not aligned with an ideally rational say, Betty's coherent rejections do not count as evidence that $\varphi$ is not justified. Thus, her standing is low in purchase, or lower than in JP1.

Discursive standing can vary in purchase also in a single justification practice. One factor that determines purchase is how readily available it is for people to meet salient authoritativeness constraints. Other things being equal, the more readily available this is

\footnotetext{
${ }^{22}$ This simplifies. Hypotheticalization must add constraints that suffice for authoritativeness. Yet Larmore construes reasonableness in thin epistemic terms that make it only necessary for authoritativeness. Thus, discursive input must arguably also cohere with other things, such as the commitment to "prize most highly the norms of rational dialogue and equal respect" (Larmore 1996, p. 142). For now, I put things in terms of reasonableness and take the latter to suffice for authoritativeness. On reasonableness in Larmore: see Macedo 1991, p. 260f, and [omitted for blind review].

${ }^{23}$ The following applies to the present case the account of discursive equality proposed in [omitted for blind review], [omitted for blind review].
} 
for an agent, the more will her standing resemble Betty's standing in JP1. And the less available this is, the more will it resemble Betty's standing in JP2. At the limit, discursive practice can put it out of the actual reach of people to exercise any relevant level of discursive influence: thus, while people might notionally have a justificatory say, their standing might have little discursive purchase.

A final matter worth highlighting now concerns justification practices that adopt non-trivial authoritativeness constraints-constraints, that is, that not every relevant agent readily meets anyway. Where agents relevantly differ in their deliberative resources, such constraints often are not equally available to them. As a result, their discursive standing will differ in purchase. E.g., if authoritative input must at least be thoughtful and coherent, always-thoughtful-and-coherent Betty's voice always qualifies as authoritative (thus, her standing is like Betty's in JP1), while rarely-thoughtful-andcoherent Paul's voice rarely does (and so his standing is like Betty's in JP2). Now, actualist public justification includes in its constituency real people and instantiates in contexts of actual interpersonal difference. Hence, it is expectable, if not unavoidable, that a practice of actualist public justification, when it applies the same non-trivial authoritativeness constraint across a diverse constituency, allocates discursive standing that differs in purchase.

This suggests we distinguish between two ways in which discursive standing can be equal. A justification practice, JP, accords $\alpha$ and $\beta$ discursive standing that is equal formally if and only if it accords $\alpha$ and $\beta$ discursive standing of the same kind (e.g., constitutive discursive standing) and applies to $\alpha$ and $\beta$ the same authoritativeness constraints (e.g., a reasonableness threshold). But JP accords $\alpha$ and $\beta$ discursive standing that is equal substantively only if it accords them standing that is equal in discursive purchase. The intuitive point: while formal discursive equality is a matter of the consistent application of salient standards to relevant agents, substantive discursive equality is a matter of the measure of discursive influence in justification, or on its outcomes, that an application of these standards leaves relevant agents with. ${ }^{24}$

\section{Equal Discursive Respect?}

LAJ can meet formal discursive equality: it accords reasonable and unreasonable citizens constitutive discursive standing and applies to all the same reasonableness threshold. But LAJ does not meet substantive discursive equality: it allocates discursive standing that is unequal in discursive purchase. To the reasonable, it allocates highpurchase standing like Betty's standing in JP1. To other people, it allocates lowpurchase standing more like Betty's standing in JP2.

If so, does LAJ model equal discursive respect? Yes and no. Yes, insofar as LAJ allocates citizens discursive standing that is equal formally. But no, insofar as LAJ does not allocate citizens standing that is equal substantively. This shifts the issue: what kind of discursive equality does equal discursive respect require? Let me

\footnotetext{
${ }^{24}$ The idea of substantive discursive equality is sympathetic with Susan Dieleman's idea of substantive inclusion (Dieleman 2015, p. 803). Substantive discursive inequality (i.e., purchase inequality), when impermissible, can instantiate an objectionable failure to include substantively in her sense. See also [omitted for blind review].
} 
assume here that equal discursive respect requires at least formally equal discursive standing: for LAJ to extend to $\alpha$ and $\beta$ equal discursive respect, LAJ must at least allocate each constitutive discursive standing and apply to them the same reasonableness threshold. Does this suffice?

Intuitively, it does not. Discursive standing that is equal formally can be objectionably unequal in purchase. Consider JP3: it accords all citizens constitutive discursive standing and applies to all the same authoritativeness constraint, $\psi$. Let JP3's constituency include Dominant Group and Marginal Group, and assume that Dominant Group has used its influence to define $\psi$ in terms of values that its members accept and other people reject: in JP3, discursive input counts as authoritative only insofar as it coheres with Dominant Group Values. Thus, while members of Dominant Group have a standing like Betty in JP1, others have a standing like Betty in JP2. JP3 satisfies formal discursive equality. But it does not treat people as discursive equals or accord them (some purchase-sensitive form of) "equal opportunity for political influence" (Cohen 2006 , p. 242) or equal "opportunities to participate in the process of public deliberation” (Peter 2009, p. 67). Rather, JP3 entrenches the dominance of Dominant Group: it turns justification practice itself into a vehicle of domination, marginalization, or worse. And it is not a big stretch to see similarities between the standing of members of Marginal Group in JP3 and the standing of the unreasonable in LAJ.

Perhaps, then, LAJ can model equal discursive respect only if it allocates standing that is equal formally and substantively-i.e., if it satisfies discursive equity ([omitted for blind review])? LAJ cannot do this. But neither will any real-life practice of public justification that applies non-trivial authoritativeness constraints across real-life, diverse constituencies that include agents who relevantly differ in their deliberative resourcesrelevantly, that is, so as to affect how available it is for them to meet these constraints. If real-life public justification can model equal discursive respect, then, equal discursive respect cannot require discursive equity.

A third view is this: equal discursive respect allows for differences in discursive purchase, but not every form of purchase inequality is compatible with it. On this view, LAJ can extend $\alpha$ and $\beta$ equal discursive respect even if LAJ accords $\alpha$ and $\beta$ discursive standing that is unequal substantively if their standing does not impermissibly differ in discursive purchase. As far as this goes, this, I assume, is plausible. But it implies that we cannot know whether LAJ models equal discursive respect unless we know whether LAJ allocates permissible purchase inequality. Thus, the question shifts again: when is purchase inequality permissible, or just? ${ }^{25}$

Let me bring this back to the exclusion objection. I asked whether hypotheticalizing actualist public justification can accommodate this objection. To explore the matter, I considered whether LAJ can model equal discursive respect. The above suggests a nuanced answer. LAJ can accord discursive standing that is equal formally. In one respect, then, LAJ can model discursive equality. But we have also seen that this does not suffice to accommodate the exclusion objection if equal discursive respect requires not only formal discursive equality, but also the absence of impermissible purchase inequality. Thus: even if hypotheticalized actualist public justification accords formally equal discursive standing to unreasonable citizens, it cannot model equal discursive

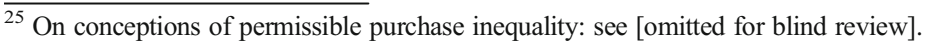


respect, or accommodate the exclusion objection, unless its allocation of purchase inequality is permissible.

Now, we saw that some level of purchase inequality is permissible if actualist public justification across a diverse constituency can model equal discursive respect. But it is open whether LAJ's allocation of purchase inequality is permissible. And while this seems doubtful from the perspective of the exclusion objection, political liberals like Larmore are evidently committed to the view that LAJ's level of purchase inequality is permissible. Thus, proponents and critics of actualist political liberalism are left with two questions:

(i) Who should be accorded a justificatory say in political liberalism's practices of actualist public justification (or: to whom should such justification extend equal discursive respect)?

(ii) What level of substantive discursive inequality is permissible within such practices, or is compatible with equal discursive respect (or: when are purchase inequalities in such practices permissible, or just)?

Hypotheticalizing actualist public justification can answer (i) in a manner that goes LAJ includes the unreasonable, it does so by allocating discursive standing that involves high levels of purchase inequality. And with this the issue now turns on an answer to (ii). Thus, how should we answer (ii)? What view of the permissibility of purchase inequality-or of purchase justice, for short ([omitted for blind review])should be adopted here? On this, the jury is still out.

\section{Conclusion}

This paper suggested that Rawls-type political liberalism puts center stage a conception of public justification that is actualist and fundamental. I sketched aspects of this conception and considered in this light the exclusion objection to political liberalism. We saw that also a Larmore-type hypotheticalized version of actualist and fundamental public justification cannot overcome this objection: insofar as it remains open whether LAJ allocates a permissible form of purchase inequality, it remains open whether LAJ expresses, or models, equal discursive respect. Yet rather than proving compelling grounds to reject political liberalism, this consideration leads to deeper questions about the nature of discursive equality in public justification.

In closing, I make a general observation. The above left open how political liberalism defines APJ's idea of the reasonable, although I assumed that this idea is rich enough in content to invite the exclusion objection. Now, as has often been noted, there can be many versions of political liberalism depending on what idea of the reasonable it builds on (Nussbaum 2011; Besch 2012; Wall 2014; Billingham 2017). As a rule of thumb, the thinner in contested moral or political content this idea is, the more inclusive, or less exclusionary, APJ is-but the more inclusive it is, the more doubtful it must be that a political liberalism qualifies as reasonable in APJ's then- 
discursive respect and its other, lower-order substantive moral or political commitments. But so long as it attempts to reconcile these things by premising APJ on a nontrivial reasonableness threshold-one that not every relevant person meets anyway-it invites the question whether APJ, in this more inclusive form, allocates only permissible purchase inequality. The issue of purchase inequality hence would be a matter of concern also for more inclusively inclined forms of actualist political liberalism.

Of course, it does not stop here. Purchase inequality is a matter of concern for every conception of acceptability-based justification that aims to express, or model, equal discursive respect for actual people. On such conceptions, discursive practice must satisfy discursive equality. But once we recognize that discursive standing can be equal formally while being (objectionably) unequal substantively, it quickly becomes opaque what exactly discursive equality calls for. ${ }^{26}$ Thus, what distinguishes permissible from impermissible purchase inequality? Again, if this is open, it is open what it takes for practices of actualist public justification to model equal discursive respect. And so long as this is open, the ability of such practices to provide justification must be in doubt.

\section{References}

Baderin, A. (2017). Reflective equilibrium: Individual or public? Social Theory and Practice., 43(1), 1-28.

Besch, T. M. (1998). Über John Rawls’ politischen Liberalismus. Frankfurt am Main: P. Lang.

Besch, T. (2012). Political liberalism, the internal conception, and the problem of public dogma. Philosophy and Public Issues, 2(1), 153-177.

Besch, T. M. (2014). On discursive respect. Social Theory and Practice., 40(2), 207-231.

Besch, T. M. (2019). On justification, idealization, and discursive purchase. Philosophia., 47(3), 601-623.

Billingham, P. (2017). Liberal Perfectionism and Quong's Internal Conception of Political Liberalism. Social Theory and Practice, 43(1), 79-106.

Campos, P. F. (1994). Secular Fundamentalism. Columbia Law Review., 94(6), 1814-1827.

Cohen, J. (2006). Is there a human right to democracy? In C. Sypnowich (Ed.), The egalitarian conscience (pp. 226-248). Oxford: Oxford University Press.

Daniels, N. (1979). Wide reflective equilibrium and theory acceptance in ethics. The Journal of Philosophy., 76(5), 256-282.

Daniels, N. (1980). Reflective equilibrium and Archimedean points. Canadian Journal of Philosophy., 10(1), 83-103.

DePaul, M. (1993). Balance and refinement. London: Routledge.

Dieleman, S. (2015). Epistemic justice and democratic legitimacy. Hypatia., 30(4), 794-810.

Doppelt, G. (1988). Rawls' Kantian ideal and the viability of modern liberalism. Inquiry., 31(4), 413-449.

Doppelt, G. (1989). Is Rawls's Kantian liberalism coherent and defensible? Ethics., 99(4), 815-851.

Enoch, D. (2015). Against public reason. In D. Sobel, P. Vallentyne, \& S. Wall (Eds.), Oxford studies in political philosophy (Vol. 1, pp. 112-144). Oxford: Oxford University Press.

Estlund, D. (1998). The insularity of the reasonable: Why political liberalism must admit the truth. Ethics., $108(2), 252-275$.

Forst, R. (2017a). Normativity and power: Analyzing social orders of justification. Oxford: Oxford University Press.

Forst, R. (2017b). Political liberalism: A Kantian view. Ethics., 128(1), 123-144.

Friedman, M. (2000). John Rawls and the political coercion of unreasonable people. In V. Davion \& C. Wolf (Eds.), The idea of a political liberalism: Essays on Rawls (pp. 13-33). Oxford: Rowman \& Littlefield.

Gaus, G. (1999). Reasonable pluralism and the domain of the political: How the weaknesses of John Rawls's political liberalism can be overcome by a justificatory liberalism. Inquiry., 42(2), 259-284.

860

861

862

863

864

865

866

867

868

869

870

871

872

873

874

875

876

877

878

879

880

881

882

883

884

885

886

887

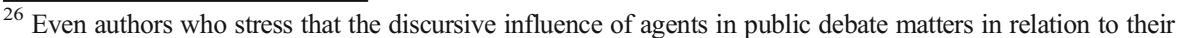
standing as discursive equals often do not examine in detail what would constitute a just measure of such influence, or what would justify it as just: see Peter 2009, chapters 5 and 7; Dieleman 2015, or Forst, 2017a, chapter 2. For one attempt to systematically explore the matter: see [omitted for blind review].
} 
Gaus, G. (2011). A tale of two sets: Public reason in equilibrium. Public Affairs Quarterly., 25(4), 305-325.

Gaus, G., \& Schoelandt, C. V. (2017). Consensus on what? Convergence for what? Four models of political liberalism. Ethics., 128(1), 145-172.

Hadfield, G., \& Macedo, S. (2012). Rational reasonableness: Toward a positive theory of public reason. The Law \& Ethics of Human Rights., 6(1), 7-46.

Hampton, J. (1989). Should political philosophy be done without metaphysics? Ethics., 99(4), 791-814.

Hampton, J. (1993). The moral commitments of liberalism. In D. Copp, J. Hampton, \& J. Roemer (Eds.), The idea of democracy (pp. 292-313). Cambridge: Cambridge University Press.

Kelly, T., \& Mcgrath, S. (2010). Is reflective equilibrium enough? Philosophical Perspectives., 24(1), 325-359.

Knight, C. (2006). The method of reflective equilibrium: Wide, radical, fallible, plausible. Philosophical Papers, 35(2), 205-229.

Laden, A. (2014). Constructivism as rhetoric. In J. Mandle \& D. Reidy (Eds.), A companion to Rawls (pp. 5972). Hoboken: John Wiley \& Sons, Inc..

Larmore, C. (1996). The morals of modernity. Cambridge: Cambridge University Press.

Larmore, C. (1999). The moral basis of political liberalism. The Journal of Philosophy., 96(12), 599-625.

Larmore, C. (2008). The autonomy of morality. Cambridge: Cambridge University Press.

Larmore, C. (2015). Political liberalism: Its motivation and goals. In D. Sobel, P. Vallentyne, \& S. Wall (Eds.), Oxford Studies in Political Philosophy (Vol. 1, pp. 63-88). Oxford: Oxford University Press. LeBar (2008b).

Lister, A. (2008). Reflective Equilibrium: Epistemological or Political? Windsor Yearbook of Access to Justice., 26(2), 266-279.

Lister, A. (2017). Public reason and reciprocity. Journal of Political Philosophy., 25(2), 155-172.

Macedo, S. (1990). The politics of justification. Political Theory, 18(2), 280-304.

Macedo, S. (1991). Liberal virtues. Oxford: Oxford University Press.

Mulhall, S., \& Swift, A. (1996). Liberals and communitarians (2nd ed.). Oxford: Blackwell.

Nielsen, K. (1994). How to proceed in social philosophy: Contextualist justice and wide reflective equilibrium. Queen's Law Journal., 20(1), 89-138.

Nussbaum, M. (2011). Perfectionist liberalism and political liberalism. Philosophy \& Public Affairs, 39(1), 3-45.

O’Neill, O. (1996). Toward justice and virtue. Cambridge: Cambridge University Press.

O’Neill, O. (2015). Changing constructions. In T. Brooks \& M. Nussbaum (Eds.), Rawls's political liberalism (pp. 57-72). New York: Columbia University Press.

Peter, F. (2009). Democratic Legitimacy. New York: Routledge.

Postema, G. (1995). Public practical reason: An archeology. Social Philosophy and Policy., 12(1), $43-86$.

Quong, J. (2011). Liberalism without perfection. Oxford: Oxford University Press.

Quong, J. (2012). Replies to Gaus, Colburn, Chan, and Bocchiola. Philosophy and Public Issues., 2(1), 51-79.

Quong, J. (2014). On the idea of public reason. In E. Mandle \& D. Reidy (Eds.), A companion to Rawls (pp. 265-280). Hoboken: John Wiley \& Sons.

Rawls, J. (1971). A theory of justice. Cambridge: Belknap Press of Harvard University Press.

Rawls, J. (1974). The Independence of moral theory. Proceedings and Addresses of the American Philosophical Association., 48, 5-22.

Rawls, J., \& Kelly, E. (2001). Justice as fairness: A restatement. Cambridge: Harvard University Press.

Rawls, J. (2005). Political liberalism (Expanded ed.). New York: Columbia University Press.

Raz, J. (1882). The claims of reflective equilibrium. Inquiry., 25(3), 307-330.

Scanlon, T. (2002). Rawls on justification. In S. Freeman (Ed.), The Cambridge companion to Rawls (pp. 139-167). New York: Cambridge University Press.

Schoelandt, C. V. (2015). Justification, coercion, and the place of public reason. Philosophical Studies, 172(4), 1031-1050.

Wall, S. (2014). Perfectionism, reasonableness, and respect. Political Theory, 42(4), 468-489.

Wall, S. (2016). The pure theory of public justification. Social Philosophy and Policy, 32(2), 204-226.

Weithman, P. (2011). Why political liberalism? New York: Oxford University Press.

Weithman, P. (2015). Legitimacy and the project of political liberalism. In T. Brooks \& M. Nussbaum (Eds.), Rawls's political liberalism (pp. 73-112). New York: Columbia University Press.

Weithman, P. (2017). In defense of a political liberalism. Philosophy \& Public Affairs., 45(4), 397-412.

Wenar, L. (1995). 'Political liberalism': An internal critique. Ethics., 106(1), 32-62.

888

889

890

891

892

893

894

895

896

897

898

899

900

901

902

903

904

905

906

907

908

909

910

911

912

913

914

915

916

917

918

919

920

921

922

923

924

925

926

927

928

929

930

931

932

933

934

935

936

937

938

939

940

941

942

943

institutional affiliations. 